\title{
New evidence of spontaneous cure in human Chagas' disease
}

\author{
Novas evidências da cura espontânea da doença de Chagas humana \\ Sonia S. Francolino', Antonio Fernandez Antunes ${ }^{2}$, Rodolfo Talice ${ }^{3}$, \\ Rachel Rosa ${ }^{4}$, Joel Selanikio ${ }^{5}$, Joffre Marcondes de Rezende ${ }^{6}$, \\ Álvaro J. Romanha ${ }^{7}$ and João Carlos Pinto Dias ${ }^{7}$
}

\begin{abstract}
A new case of spontaneous cure of human Chagas' disease is described in Uruguay. An 87-year-old man who had a typical acute phase of Trypanosoma cruzi infection in 1947 and never received specific treatment against the disease, when examined in 1998 revealed several completely negative parasitological and serological tests, including traditional serology, PCR and flow cytometry. As a whole, such findings fulfill the current criteria to define the cure of Chagas' disease. Clinical data suggest the possibility of a benign evolution of Chagas' disease in this case, but the basic findings (slight cardiac and esophageal impairment) could also be due to the advanced age of the patient.
\end{abstract}

Key-words: Trypanosoma cruzi. Chagas'disease. Spontaneous cure.

Resumo Um novo caso de cura espontânea da doença de Chagas humana é descrito no Uruguai. Um homem de 87 anos de idade que teve um quadro típico de doença de Chagas aguda em 1947 e nunca recebeu tratamento específico, revelou-se em 1998 completamente negativo para exames sorológicos e parasitológicos, inclusive por PCR e citometria de fluxo. Estes achados, no conjunto, preenchem os critérios correntes para a definição de cura da doença de Chagas. O quadro clínico atual sugere a possiblidade de uma evolução benigna da doença de Chagas, mas os achados principais (comprometimento leve do coração e do esôfago) poderiam também dever-se à avançada idade do paciente.

Palavras-chaves: Trypanosoma cruzi. Doença de Chagas. Cura espontânea.

Since his pioneering works, Carlos Chagas stated that once infected by Trypanosoma cruzi (T. cruzi), a chagasic individual generally would continue with the infection for the rest of his life, always presenting high levels of specific antibodies in the chronic phase of Human Chagas' Disease (HCD) ${ }^{4}$. Several longitudinal studies in endemic and non-endemic areas have shown this persistence of antibodies in chagasic individuals during many years. On the other hand, some naturally or experimentally infected mammals, such as pigs, goats, horses and cattle have shown very discrete parasitaemia at the beginning of the infection which frequently disappears totally at the chronic phase. In larger animals, serology has also become negative after a brief period of parasitaemia, immediately after the inoculation, suggesting an elimination of infection ${ }^{151720}$.
In human beings, after successful parasitological treatment in both acute and chronic phase serology becomes negative, thereby indicating the absence of the parasite from the organism, signifying cure of the infection 3512131415 . However, spontaneous cure of HCD had never been detected before 1988, when Zeledón et al. reported some cases that became serological and parasitologically negative without specific treatment three decades after their acute onset ${ }^{25}$ Likewise, this possibility has been mentioned in Chile and Brazil but, in general, the authors consider that spontaneous cure must be understood as an exceptional situation in the natural history of HCD 52132025 . Similarly, another similar case was reported in Uruguay that was detected in 1998, during a routine international supervision of the National Chagas Disease Program in the city of Paysandu.

\footnotetext{
1. Haematologist, Blood Bank Director. Paysandu, Uruguay. 2. Cardiologist, Paysandu, Uruguay. 3. Parasitologist of National University, Montevideo, Uruguay (dead in 1999). 4. Chief of Chagas Disease Control Program. Montevideo, Uruguay; 5. Epidemiologist of the CDC-Atlanta, USA. 6. Full Professor Federal University of Goiás, Goiânia, GO, Brazil. 7. Senior Researcher. Centro de Pesquisas René Rachou da Fundação Oswaldo Cruz, Belo Horizonte, MG, Brazil. Address to: Dr. João Carlos Pinto Dias. Centro de Pesquisas René Rachou/FIOCRUZ. Av. Augusto de Lima 1715, Barro Preto, 30190-002 Belo Horizonte, MG, Brazil.

E-mail:jcpdias@cpqrr.fiocruz.br

Recebido para publicação em 3/12/2002.
} 


\section{CASE REPORT}

PER, 78 years old, male, Caucasian, agriculture worker, Russian immigrant. Arriving in Uruguay during 1946, he was immediately transferred to the rural zone of Paysandu county, where he has been living until today. At that time, this entire region was highly infested by Triatoma infestans infected by $T$. cruzi, resulting in numerous acute cases, several of them published by Talice et $\mathrm{al}^{22}$. The patient himself informs clearly that his first rural house in Paysandu was infested by vinchucas at that time and that many times he was bitten by them during the night. In July 1998, PER presented himself as a volunteer for blood donation at the Paysandu Blood Bank, where serology for HCD was performed and resulted negative*. Nevertheless, during the routine medical examination, the patient declared that he had HCD since 40 years ago, having been attended by Prof. Rodolfo Talice at the Hospital Maciel (Ministry of Health) in Montevideo. The original hospital records indicate that this patient was attended by Prof. Talice on May 7, 1947, with fever and Romaña's sign, positive direct blood examination (concentrated drop) for T. cruzi. EKG showed only general disturbances of repolarization and synusal rhythm with normal PR interval and a frequency of $90 \mathrm{hb} /$ minute. According to the patient, xenodiagnosis was also positive at that time, but no official records were found. No specific treatment was performed and the

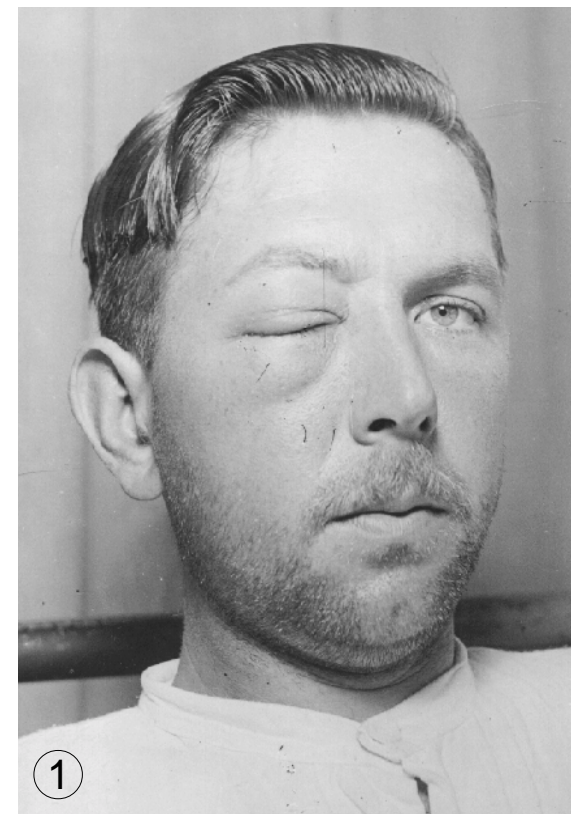

Figure 1 - Mr. PER in 1947. Note Romaña's sign (right eye). (photo by Prof. $R$. Talice). patient left the hospital without fever, within two weeks. A picture of his very typical Romaña's sign was taken and published in the Salveraglio's Enfermedades Infecciosas Medical textbook by Talice, page 394 (Figure 1) ${ }^{21}$. In Paysandu PER remained healthy and asymptomatic during the last 40 years, never again being examined or specifically treated for Chagas' Disease. No information about serology for HCD was available or referred by the patient between 1947 and 1998. During this time the patient reports good health, never requiring medical assistance, hospitalization, surgery or blood transfusion. Present medical examination: the only complaint is a first degree stable dyspnea (on major physical effort) in the last two years. No swallowing disturbances or constipation were referred throughout his life. Physical examination showed no evident alterations and the basal blood pressure was 130/ $80 \mathrm{~mm}^{3} \mathrm{Hg}$., with a regular pulse of $65 \mathrm{bpm}$. Normal heart auscultation, only an hyperphonetic pulmonary second murmur being detected. No signs of heart failure. Lungs, kidney, spleen, liver and descendent colon were clinically normal. In the face, a very slight reduction of the right eyelid rift can be noted (Figure 2). Other subsidiary exams at the present time included: EKG: synusal rhythm, with rare ventricular and supraventricular ectopic beats and

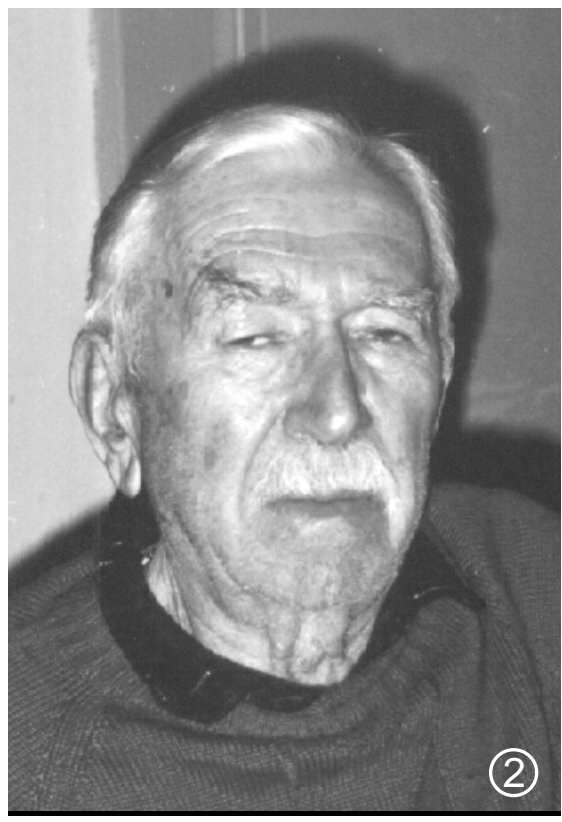

Figure 2 - Mr. PER in 1998. Note reduction of the right eyelid rift. (photo by J.C. Pinto Dias).

\footnotetext{
* Indirect haemagglutination and indirect immunofluorescence.
} 
isolated complete bundle branch block (CRBBB), with a ventricular ÂQRS axis $=100^{\circ}$ (positive). A cycloergometric test was sufficient and normal for the age, reaching $600 \mathrm{kgmts} / \mathrm{min}$. with an adequate elevation of arterial blood pressure $(170 / 90 \mathrm{mmHg}$ and CF of 120 bpm) and no disturbances in the recuperation. During the test, basal ventricular extra-systoles disappear and no $T$ waves alterations were revealed. The basal CRBBB remained unaltered. The interruption of the test was caused by leg muscle fatigue. Chest X-ray in PA position was normal (aortic discrete hypertrophy), but esophageal X-ray showed a very discrete retention of contrast one minute after swallowing (borderline from normal to anectasic first degree esophagopathy). Several specific tests to detect $T$. cruzi infection were then performed on this patient between August 1998 and December 1999, all of them resulting negative
(Table 1). Observation. To meet ethical aspects, the medical examination was made with the full voluntary cooperation of the patient, who was completely informed about his case and the clinical and laboratory examinations to which he would be submitted, as well as the right he would have to leave the examination and/ or to refuse any medical procedure at any time, according to his will. Local and Ministerial Health Authorities as well PAHO Office (Montevideo) were also informed about this case study, none of them manifesting any doubts about the work to be done. Finally, Mr. PER continues to receive permanent medical attention from one of the authors (A.F.A.) until the date of this publication. In 2001 the patient was submitted to an inguinocrural hernia surgery in Paysandu with peridural anesthesia, presenting very good follow up and no intrasurgical complications.

\begin{tabular}{llll}
\multicolumn{2}{l}{ Table 1 - Laboratory } & examinations for Trypanosoma cruzi infection in the patient PER between 1998 and 2000. \\
\hline Date & Test & Result & Observations \\
\hline July/1998 & IIT and IHT & negative & Paysandu Blood Bank \\
August/1998 & IIT, ELISA \& IHT & negative & FUNED/Belo Horizonte, Brazil \\
August/1998 & IIT \& IHT & negative & Fac Medicine/Montevideo, Uruguay \\
August/1998 & IIT, ELISA & negative & CDC/Atlanta, USA \\
August/1998 & flow cytometry & negative & FIOCRUZ/Belo Horizonte, Brazil \\
September/1998 & PCR & negative & FIOCRUZ/Belo Horizonte, Brazil \\
November/1998 & PCR & negative & FIOCRUZ/Belo Horizonte, Brazil (repetition) \\
February/1999 & IIT, ELISA \& IHT & negative & Fac Medicine/Goiânia, Brazil \\
June/1999 & xenodiagnosis & negative & Fac Medicine/Montevideo, Uruguay \\
December/1999 & xenodiagnosis & negative & Fac Medicine/Montevideo, Uruguay
\end{tabular}

IIT = indirect immunofluorescence test; IHT = indirect hemoagglutination test;

Xenodiagnosis: 40 Triatoma infestans nymphs, examined at 30 and 60 days

The parasite DNA research was made by PCR technique, utilizing the phenol-chloroform method for extraction, according to Diaz et al ${ }^{8}$.

\section{DISCUSSION}

This case probably confirms prior very rare reports of spontaneous cure of chronic Chagas' disease described in Costa Rica, Brazil and Chile 121725 . According to the present consensus among HCD experts, a permanent absence of specific antibodies and parasitic evidence strongly suggests the nonexistence of chagasic infection, this criterion being utilized to indicate the cure of treated patients 3713152425 . Very singular cases of absence of antibodies in immunodeficient chagasic individuals have been reported, but generally such patients show high peripheral parasitaemia, easily detected by xenodiagnosis and/or $\mathrm{PCR}^{89}{ }^{13}$. The evidence of an acute phase of the disease 41 years ago in this patient was stated by direct examination (official records) and xenodiagnosis (referred by the patient), as well as the fact that his picture was published by Prof. Talice in a Medical textbook, to illustrate a typical case of acute $\mathrm{HCD}^{6} 101120$. Unfortunately, no records of serology were found in this patient's antecedents. According to all available records and evidence, PER presented a typical and benign acute phase of $\mathrm{HCD}$ and naturally entered in the chronic phase within a few weeks of clinical course, without specific treatment. The typical Romaña's sign (Figure 1) and both information from the patient and Dr. Talice's records leave no doubt that PER presently examined is the same person registered in 1947 and that he was contaminated by the vector route. This route is most probable since the patient had just arriving from Russia (a non-endemic country) and never received blood transfusion in his life. On the other hand, Paysandu region was highly infested by $T$. infestans at that time, with a general infection rate due to $T$. cruzi of $47 \%$. According to Talice et $\mathrm{a}^{22}$. It should also be underscored that Paysandu was the origin of the first case of HCD registered in Uruguay and that $35 \%$ of the cases reported by Talice et al originated from this region $^{22}$. Electrocardiographical benign alterations in the acute phase of this patient show a diffuse and slight myocardial involvement, with favorable prognosis, chiefly in the absence of clinical signs of acute heart failure ${ }^{511} 2024$. Another factor of good prognosis was the age of this 
patient during the acute onset, since deaths and severe clinical pictures are always detected in younger patients and experimental animals ${ }^{1410}$. To date, the clinical course of this patient was very good and specific treatment was never initiated. It must be emphasized that at that time no effective drugs against $T$. cruzi were available and that Dr. Talice himself had tried in 1945 an arsenical drug in acute HCD cases, with no influence in clinical course and only slight influence in the parasitaemia of only a few cases studied ${ }^{23}$. The central aspect of this case concerns the complete and permanent disappearance of his $\lg G$ antibodies 41 years after the acute phase of HCD, which indicates the absence of the parasite in healthy individuals or, in other words, cure of the infection ${ }^{13} 141525$. Such a hypothesis is also reinforced here by the negative result of flow cytometry, a very specific test to detect the lytic protector antibodies which indicate the existence of live parasites ${ }^{3131415}$. The cure was also supported by parasitological tests, namely two negative xenodiagnosis and two PCR assays ${ }^{81215}$. Clinically, the present examination of this patient shows an elderly man with slight heart and esophageal impairment which could be due to T. cruzi infection, according to several observations in Latin American endemic countries ${ }^{7} 1618$ 24. Nevertheless, the cardiac involvement (CRBBB \& extra-systolic beats) as well as the first degree esophageal dysperistalsis can also appear in elderly non-chagasic individuals, as a result of myocardial sclerosis and physiologic esophagus denervation (presby-oesophagus), thus making it almost impossible to determine the central etiological component of the present clinical picture ${ }^{718}$. As a general rule and considering a series of longitudinal studies, the most probable is that both factors have been involved in this evolution, since the patient certainly had an acute phase of HCD, in which myocytolysis and autonomic denervation generally occurs ${ }^{1251020}$. The basic difference between this case and the ones detected earlier in Costa Rica is just the present clinical picture, because those cases were in the chronic indeterminate form, with no cardiac and/or digestive detected disturbances ${ }^{25}$. Not only the age of the patients can explain this clinical difference, since the Costa Rican individuals were much younger than $\mathrm{PER}^{5}{ }^{25}$. Also geographical differences might be involved, since the parasite strains are not the same, as well as the regional vectors (Triatoma dimidiata in Costa Rica: and T. infestans in Uruguay); since in general terms, it is accepted that the morbidity of HCD is usually more severe in the Southern Cone than in Central America7 202425 .

\section{ACKNOWLEDGEMENTS}

The authors are indebted to Dr. Olindo Martins Filho (FIOCRUZ), Dr. Alejandro Luquetti (Goiás University) and Dr. Roberto Salvatella (PAHO, Uruguay) for their valuable help in complementary serology and epidemiological data of this case.

\section{REFERENCES}

1. Andrade ZA. Patologia da Doença de Chagas. Trypanosoma cruzi e doença de Chagas, $2^{\text {nd }}$ edition, Guanabara Koogan Editora, Rio de Janeiro, p. 201-230, 1999.

2. Arribada A, Apt W, Ugarte IM. A four year follow-up survey of chagasic cardiopathy in Chile.Bulletin of Pan American Health Organization 20: 240-266, 1986.

3. Cançado JR. Terapêutica Específica. In:Dias JCP, Coura JR (eds) Clínica e Terapêutica da Doença de Chagas. Uma Abordagem Prática para o Clínico Geral. Editora da Fundação Oswaldo Cruz, Rio de Janeiro, p. 323-342, 1997.

4. Chagas CRJ. Clinical and anatomo-pathologic aspects of American Trypanosomiasis. Medical Surgery Journal 12: 630660,1920

5. Dias JCP. História Natural. In: Cançado JR, Chuster M (eds) Cardiopatia Chagásica. Editora da Fundação Carlos Chagas, Belo Horizonte, p. 99-113, 1984.

6. Dias JCP. Acute Chagas' disease. Memórias do Instituto Oswaldo Cruz 79 (supl): 85-92, 1984

7. Dias JCP, Coura JR. Epidemiologia. In: Dias JCP, Coura JR (eds) Clínica e Terapêutica da Doença de Chagas. Uma Abordagem Prática para o Clínico Geral. Editora da Fundação Oswaldo Cruz, Rio de Janeiro, p. 33-66, 1997.

8. Diaz C, Nussenzweig V, Gonzalez A. An improved polymerase chain reaction assay to detect Trypanosoma cruzi in blood. The American Journal of Tropical Medicine and Hygiene 46: 616-623, 1990.
9. Ferreira MS, Nishioka SA, Rocha A, Silva AM. Doença de Chagas e Imunossupressão. In: Dias JCP, Coura JR (eds) Clínica e Terapêutica da Doença de Chagas. Uma Abordagem Prática para o Clínico Geral. Editora da Fundação Oswaldo Cruz, Rio de Janeiro, p. 365-382, 1997.

10. Laranja FS, Dias E, Nóbrega GC, Miranda A. Chagas' disease. A clinical, epidemiologic and pathologic study. Circulation 14: 10351060, 1956

11. Lugones $H$, Ledesma $O$, Storino $R$, Marteleur A, Meneclier CR, Barbieri C. Chagas Agudo. In:Storino R, Milei J (eds) Enfermedad de Chagas. Doyma Argentina Editorial, Buenos Aires, p. 209234, 1994.

12. Luquetti $A O$. Diagnóstico laboratorial da infecção pelo Trypanosoma cruzi. In:Brener Z, Andrade ZA, Barral-Neto M (eds) Trypanosoma cruzi e doença de Chagas, $2^{\text {nd }}$ edition, Rio de Janeiro: Guanabara Koogan Editora, p. 344-378, 1999.

13. Luquetti AO, Rassi A. Tratamiento específico de la enfermedad de Chagas en la fase crónica: criterios de cura convencionales: xenodiagnóstico, hemocultivos y serología. Revista de Patologia Tropical 27 (supl):37-50, 1998.

14. Organización Panamericana de la Salud. Tratamiento etiológico de la enfermedad de Chagas. Conclusiones de una consulta técnica. Documento OPS/HCP/HCT/1140/99, Washington, 1999.

15. Martins Filho OA, Pereira MES, Carvalho JF, Cançado JR, Brener Z. Flow cytometry, a new approach to detect anti-live 
trypomastigote antibodies and monitor the efficacy of specific treatment in human Chagas' disease. Clinical Diagnosis and Laboratorial Immunology 2: 569-573, 1995.

16. Prata AR. Abordagem geral do paciente chagásico. In: Dias JCP, Coura JR (eds) Clínica e Terapêutica da Doença de Chagas. Uma Abordagem Prática para o Clínico Geral. Editora da Fundação Oswaldo Cruz, Rio de Janeiro, p. 115-126, 1997.

17. Puigbó JJ, Nava Rhode JR. Barrios HG, Yepes CG. Cuatro años de estudio longitudinal de una comunidad rural con endemia chagásica. Boletín de la Oficina Sanitaria Panamericana 48: 112-120, 1969.

18. Rezende JMO. $O$ aparelho digestivo na doença de Chagas: aspectos clínicos. In: Dias JCP, Coura JR (eds) Clínica e Terapêutica da Doença de Chagas. Uma Abordagem Prática para o Clínico Geral. Editora da Fundação Oswaldo Cruz, Rio de Janeiro, p. 153-176, 1997.

19. Salgado AA, Mayrink W, Dias JCP. Estudo comparativo entre a reação de fixação de complemento com os antígenos benzeno cloroformado e metílico e o xenodiagnóstico. Revista do Instituto de Medicina Tropical de São Paulo 12: 36-40, 1970.
20. Storino R, Milei J, Manzullo E, Darraidou M. Evolución Natural y Estudios Longitudinales. In: Storino R, Milei J (eds) Enfermedad de Chagas. Doyma Argentina Editorial, Buenos Aires, p. 593-604, 1994.

21. Talice RV. Epidemiologia y profilaxis de las tripanosomiasis (Enfermedad del Sueño. Enfermedad de Chagas). In:Salveraglio FJ (ed) Enfermedades Infecciosas. Inter-Médica Editorial, Buenos Aires, p. 390-399, 1949

22. Talice RV, Costa S, Rial B, Osimani JJ. Enfermedad de Chagas (Tripanosomiasis americana). Instituto de Higiene de Montevideo Editora, Montevideo,1940.

23. Talice RV, Fernandez JL. Primeros ensayos de tratamiento de las formas agudas de enfermedad de Chagas con un nuevo arsenical. Archivos Uruguayos de Medicina, Cirurgía y Especialidades XXVII (1): 33-46, 1945.

24. World Health Organization. Chagas Disease Control. Technical Series Report n॰ 811, 1991

25. Zeledón R, Dias JCP, Brilla-Salazar A, Rezende JM, Vargas LG, Urbina A. Does a spontaneous cure for Chagas' disease exist? Revista da Sociedade Brasileira de Medicina Tropical 21: 15-20, 1988. 